\title{
Rawls's Thin (Millean) Defense of Private Property
}

\author{
JOSEPH PERSKY \\ University of Illinois at Chicago
}

This article suggests that Rawls's break with early utilitarians is not so much over the greatest happiness principle as it is over the relation of the institution of private property to justice. In this respect Rawls is very close to John Stuart Mill, arguing for a cleansed or tamed version of the institution. That said, Rawls's defense of private property remains very thin and highly idealized, again following Mill. If Hume and Bentham fail to demonstrate their claims, Rawls and Mill do little better. Rawls, like Mill, has constructed a challenging standard, admits to severe limitations on our empirical knowledge, and remains deeply ambivalent over the role of private property.

\section{INTRODUCTION}

After enunciating his two principles of justice, John Rawls turns to describing sets of institutions consistent with those principles and capable, he hopes, of providing an appropriate background for justice. Explicitly included in at least one realization of Rawls's 'basic structure' is a version of the institution of private property, a 'propertyowning democracy', borrowed from the work of James Meade. Rawls's position hardly constitutes a strong defense of private property. Rather his defense of property, if it is a defense, remains thin and quite conditional. In this respect Rawls very much resembles the nineteenthcentury utilitarian John Stuart Mill. I suspect that this similarity isn't accidental and that the character of Rawls's limited defense is the product of much the same forces as those shaping Mill's. In previous work I have argued that early utilitarian defenses of property attempted to present as trivial questions that taken seriously were near to impossible given the social science of the day. This lack of knowledge was further complicated by a deep ambivalence over the institution itself. $^{1}$ The present article offers a parallel analysis of Rawls's defense of private property and attempts in the process to draw out the deeper similarities between Rawls and John Stuart Mill.

\section{RELEVANCE: PROPERTY AND RAWLS'S PROGRAM}

Many economists commenting on Rawls assume he was talking about the optimal organization of a welfare state. Thus they have

1 J. J. Persky, 'On the Thinness of the Utilitarian Defense of Private Property', Journal of the History of Economic Thought (2009). 
become used to treating John Rawls's notions about justice as a guide to taxation and income redistribution. The Rawlsian social welfare function, $\min \left(\mathrm{U}_{1}, \mathrm{U}_{2}, \ldots \mathrm{U}_{\mathrm{N}}\right)$ is viewed as a dramatic alternative to be addressed in problems of welfare maximization in public finance. ${ }^{2}$ Such exercises undoubtedly lead to useful analysis. However, this interpretation of Rawls distorts considerably his basic concerns. ${ }^{3}$ Rawls wasn't propounding some novel progressive income tax code. Indeed, his comments on the subject suggest that he favored a flat tax. Rawls introduced his principles with bigger game in mind. He advanced them as the basis for evaluating the basic institutional regimes of societies. For Rawls, the question is not whether we have set up a system of taxes and transfers to maximize the minimum utility in society, but whether the institutions of society are just. And among these institutions is that of private property.

Modern economists generally avoid questions of justice in favor of analyses of efficiency. Even when economists venture into questions of redistribution, they shun claims about justice. And yet the very foundations of the discipline in moral philosophy emerged out of discussions of justice. Rawls's efforts extend the work of John Stuart Mill and David Hume. While Mill and Hume can be viewed as utilitarians they were both eager to consider the question of justice in the context of their political economy. In evaluating the justice of his regimes Rawls builds directly on their platform.

John Rawls begins with an extended search for 'the most acceptable political conception of justice for specifying the fair terms of cooperation between citizens regarded as free and equal and as both reasonable and rational'. ${ }^{4}$ Rawls dubs this search 'the fundamental question of [democratic constitutional] political philosophy" ${ }^{5}$ His efforts lead to his two now famous principles of justice:

(a) Each person has the same indefeasible claim to a fully adequate scheme of equal basic liberties, which scheme is compatible with the same scheme of liberties for all.

(b) Social and economic inequalities are to satisfy two conditions: first, they are to be attached to offices and positions open to all

2 See, for example, J. Gruber and E. Saez, 'The Elasticity of Taxable Income: Evidence and Implications', Journal of Public Economics 84 (2002), pp. 1-32.

${ }^{3}$ R. Krouse and M. McPherson, 'Capitalism, "Property-Owning Democracy," and the Welfare State', Democracy and the Welfare State ed. A. Gutman (Princeton, 1988). Krouse and McPherson forcefully argue that Rawls's theory was hostile to the welfare state. Rawls subsequently endorsed their interpretation in J. Rawls, Justice as Fairness: A Restatement, ed. Erin Kelly (Cambridge, Mass., 2001).

${ }_{4}$ Rawls Restatement, pp. 7-8. Where possible I try to rely on Rawls's positions in their more or less final form as outlined in the Restatement.

${ }^{5}$ Rawls, Restatement, p. 7. 
under conditions of fair equality of opportunity; and second they are to be to the greatest benefit of the least-advantaged members of society (the difference principle). ${ }^{6}$

It is not critical to our purposes here to recount Rawls's Kantian arguments in support of his principles. Rather our concern focuses on the uses to which he puts this definition of justice. The entire exercise of deriving these principles is to serve as a basis for 'regime' choice. Rawls's agenda is about such choice. His fundamental program is to identify one or more sets of social and political institutions or 'regimes' that satisfy his criteria of justice as fairness. This is the Rawlsian payoff. $^{7}$

Presumably, regimes might differ in any number of characteristics. In practice Rawls considers only five regimes: 'state socialism with a command economy', 'liberal (democratic) socialism', 'laissezfaire capitalism', 'welfare state capitalism', and 'property-owning democracies'. As between the first two the key question is the extent of the state's planning apparatus. As between the last three the key question is the extent and character of the constraints placed on the institution of private property.

In analyzing each type of regime, Rawls acknowledges four questions that can be raised: 'the question of right', 'the question of design', the question of 'incentive compatibility', and the 'question of competence'. The last three questions are largely practical ones: Can the regime design real-world institutions to do what it wants to do? Will those institutions win citizen compliance? Will office holders actually be able to do what is expected of them? Rawls notes that much conservative thinking concerns these last three questions. He might have added much economic thinking as well. But these are not arguments he wants to engage head-on. Such arguments are not relevant to his agenda. Instead he asserts that his concerns are 'largely limited' to the first question, the question of right. Assuming the other three questions can be reasonably addressed, he asks, is a regime 'right and just?' Of course, some of us - conservatives, economists, or others - might have wished that Rawls had cast his net more broadly and explored these three other questions with respect to the regimes he considers. ${ }^{9}$ But Rawls can reasonably respond that these questions are simply

${ }^{6}$ Rawls, Restatement, pp. 42-3.

7 In his earlier work A Theory of Justice (Cambridge, Mass., 1971) Rawls hoped to achieve agreement on a 'comprehensive moral doctrine'. In his later works he advances his conception of 'justice as fairness' as a 'political conception'. In either case, the purpose of constructing the principles of justice is to facilitate the choice among social institutions.

8 Rawls, Restatement, pp. 136-7.

9 For example, Wylie Bradford (in W. Bradford, 'Rawls and Meade: Unfortunate Bedfellows?', <http://www.econ.mq.edu.au/_data/assets/pdf_file/0015/15261/8_ 
not relevant to his undertaking. Rawls has explicitly constructed the grounds upon which he moves forward and those grounds focus on the rightness and justice of institutions.

But that said, the entire point of developing the 'principles of justice' is so that they can be used to pick among differing basic institutions and thus to serve as a defense for those basic institutions. And among these is the question of property rights. In his Restatement, immediately after making the arguments for his principles, Rawls begins his exploration of 'Institutions of a Just Basic Structure', with a discussion of 'PropertyOwning Democracy'. Does such a regime answer the requirements of justice? Again, the relevant issue is not whether such a regime can exist, but whether as described it meets and supports Rawls's two principles. To suggest an affirmative answer means we have enough information about such a regime and specifically about the role of private property in such a regime to comfortably conclude that (if everything works right) it will satisfy Rawls's principles. In this eventuality, we can interpret Rawls's endorsement of a 'property-owning democracy' as a defense of private property based on the principles of justice.

By way of contrast, Rawls is clear that he judges centralized state socialism as violating the equal basic rights and liberties, not to mention the fair value of these liberties'. ${ }^{10}$ However, he does not elaborate on how he reaches this conclusion, taking it instead as largely self-evident. Rawls is convinced that state socialism with a command economy cannot be defended as a just regime. But he also explicitly rejects laissez-faire capitalism and welfare-state capitalism, both of which build on conceptions of private property endowed with broad rights. Given his rejection of these familiar versions of private property regimes, one might begin to suspect that private property, like centralized command planning, is simply not a defensible institution in terms of Rawlsian justice. But that is not Rawls's conclusion. Indeed, as noted above, he asserts that a 'property-owning democracy' will meet his basic principles. In putting forth this argument Rawls produces a highly conditional defense of private property, one that is strikingly similar to that suggested by John Stuart Mill a century before.

\section{TRIVIALITY: DRAWING ON MEADE}

Rawls's discussion of 'property-owning democracy' draws directly on the work of the economist J. E. Meade. Meade had published a short set of lectures, Efficiency, Equality and the Ownership of Property, in

${ }^{10}$ Rawls, Restatement, p. 138. 
1964. ${ }^{11}$ In A Theory of Justice, ${ }^{12}$ Rawls invokes Meade's work, but doesn't explore it in depth. In the Restatement, Rawls provides only a slightly expanded treatment. Does Meade provide a convincing defense of his property-owning democracy? Can Rawls rely on Meade's work to do the heavy lifting in his argument? Rawls seems to suggest this. But Meade's argument trivializes the role of property in the economy even as it ignores the deeper questions of justice that Rawls sees as so central.

Meade's short volume is fundamentally about automation. ${ }^{13}$ Meade is worried that while the development of more and more sophisticated physical capital is likely to increase the average productivity of labor, it is also likely to reduce the marginal productivity of labor. The result then will be a very large share of income in the hands of capital owners. We can note here that there is something rather un-neo-classical in Meade's basic scenario. As capital:labor ratios rise, Meade expects the marginal product of labor to fall. Society is faced with a rising profit rate just as profit becomes most abundant. Meade envisions what is essentially a dual economy, one in which very high capital labor ratios are applied to some primary sectors, but not to other secondary sectors.

Asserting the probability of such predictions, Meade finds the resulting world nothing short of 'hideous', a 'Brave New Capitalists' Paradise' in which 'the working population required to man the extremely profitable automated industries would be small'. $\mathrm{He}$ anticipates then 'a large expansion of the production of the labourintensive goods and services which were in high demand by the few multi-multi-multi-millionaires'. In the end 'we would be back in a superworld of an immiserized proletariat and of butlers, footmen, kitchen maids, and other hangers-on'. ${ }^{14}$

Meade's 'solution' to this highly unattractive outcome is to take advantage of his very special assumption about the duality of the automated economy. The primary economy has only a modest need for labor. The more widely and evenly spread is the ownership of private capital, the less compelling is the need to work. '[B]y the wave of some magic wand' Meade creates a society in which property is 'equally distributed over the citizens in the community'. Essentially it is a world of trust-fund babies, who receive 'a large part' of their incomes from property. In this economy work has 'become rather more a matter

11 J. Meade, Efficiency, Equality and the Ownership of Property (London, 1964).

12 Rawls, Justice.

13 Several writers, and especially Bradford (Bradford, 'Rawls and Meade'), have pointed out the rather special assumptions Meade makes with respect to automation.

14 Meade, Efficiency, p. 33. 
of personal choice', with a good deal more 'play-acting, ballet-dancing, painting, writing, sporting activities' and the like with much carried out on 'a semi-professional semi-amateur basis'. ${ }^{15}$ The resulting economy is still dual in nature, but the hypothesized egalitarian distribution of property tames the beast.

Meade trivializes the role of labor in his property-owning democracy. But in that construct he also trivializes the role of property ownership itself. Meade's property-owning democracy has largely wished away the investment incentive problem. Meade is only mildly concerned that the erosion of capital's concentration could undermine the entrepreneurial incentives that are often seen as driving productivity growth and the application of technology. In Meade's world property ownership acts as only a mild prod to accumulation. The almost universal class of small owners who work occasionally in community theaters leaves much of the decision-making in the economy to bureaucratic agents, the executives of corporations and mutual funds.

What a bland sort of property indeed. Meade acknowledges the existence of a problem, but he clearly considers it a minor one. Asserting the productiveness of private property, Meade expresses concern that in selecting among progressive tax measures to roughly maintain equality in property ownership attention should be paid to minimizing the effect on 'the incentives to work and take risks'. ${ }^{16}$ But Meade is extremely vague on just what those incentives are, what they generate for the community, and what difference it makes if the state takes major steps to distribute property more evenly. What is clearly missing is an assessment of the size and distribution of the costs (and for that matter the benefits) of taking the basic redistributive steps involved.

In Meade's tame private property, Rawls hopes to find an institution he can endorse as just - an institution that respects equal liberty and works to guarantee the highest welfare of the worst off. But in building his reform program around the special economics of automation, Meade had largely sidestepped the traditional utilitarian interpretation of the connection between property and justice. Admittedly the early utilitarians, themselves, had presented their case in a highly speculative, thin form. ${ }^{17}$ But by accepting Meade in toto, Rawls trivializes the utilitarian insights. Whatever the status of Meade's technical claims, if Rawls means to base his conditional defense of private property on the grounds of justice, he needs to address the utilitarian tradition more directly.

15 Meade, Efficiency, p. 41.

16 Meade, Efficiency, p. 54.

17 Persky, 'Thinness'. 


\section{IMPOSSIBILITY: RAWLS AND THE UTILITARIANS}

For all his protestations, Rawls shares a great deal with the utilitarians. At the very least he sees the utilitarians as his chief audience. Repeatedly he compares his own notions to those of various utilitarians. In many ways Rawls's project can be viewed as an elaboration of John Stuart Mill's effort to reconcile equality, liberty and progress. From this vantage point both Rawls and Mill are responding to early nineteenthcentury utilitarian claims about justice and the institution of private property.

The utilitarian defense of private property stretches back at least to David Hume. In his Treatise of Human Nature, Hume argued that property rights cleverly set selfishness against itself. Our avidity for acquiring goods and possessions is insatiable, perpetual, universal, and directly destructive of society'. Moreover,

no affection of the human mind has both a sufficient force, and a proper direction to counter-balance the love of gain, and render men fit members of society, by making them abstain from the possessions of others... There is no passion therefore, capable of controlling the interested affection, but the very affection itself, by an alteration of its direction. ${ }^{18}$

Far from seeing the self-interested passion as a danger to justice, Hume claimed that the very essence of justice rested on the social psychological balance he saw as stabilizing the notion of private property. Justice is not natural to the 'mind of man'. Rather it derives its origin 'from the selfishness and confin'd generosity of men, along with the scanty provision nature has made for his wants'. ${ }^{19}$

The result then is a highly utilitarian situation in which just property rights build for the greater good. The Humean turn, anticipated by Hobbes,${ }^{20}$ was not so much to destroy the wildness of the state of nature as to funnel that energy into the pursuit of property. As Hume (and Smith) maintained, such redirection doesn't exhaust those energies, rather it makes use of them in socially productive ways. Hume thus finds the very origins of justice in the social establishment of private property that simultaneously brings forth impressive material benefits. Justice and utility both flow from this social institution. They are bound together in a creative synthesis driven by the energy of self-interest.

The early utilitarians, and especially Bentham, dedicated themselves to the search for the greatest good of the greatest number. In

18 D. Hume, A Treatise of Human Nature (1740), ed. L. A. Selby-Bigge (New York, 1978), p. 492.

19 Hume, Human Nature, p. 495.

20 Rosamond Rhodes, in 'Reading Rawls and Hearing Hobbes', Philosophical Forum 33 (2002), pp. 393-412, has argued that Rawls and Hobbes share a great deal in their emphasis on 'stability and justice'. 
adopting this explicit objective function, they introduced into the utilitarian argument a commitment to optimization and maximization. Institutions must now be demonstrated as optimum optimorum. With respect to private property, the early utilitarians concluded that no other approach to motivating useful economic activity could generate anything like the abundance produced by that institution. There was simply no contest. ${ }^{21}$

Given this conclusion, the early utilitarian defense of private property went even further. Not only was the justice of private property the source of the greatest good, but that good included the poor. The poor did well because of the institution of private property. The only alternative to private property was an anarchic state of nature in which all must suffer miserably. Without security of private returns, the economy would fall back to an unattractive Hobbesian state of nature.

Jeremy Bentham saw the institution of private property as necessary to achieving the central utilitarian goal, the greatest good of the greatest number. Like Hume he took pleasure in the cleverness of the institution which thwarted the 'universal desire of man' to 'enjoy quickly' and 'without punishment'. The 'law which restrains this desire is the most splendid triumph of humanity over itself. ${ }^{22}$

But Bentham claimed more. He argued that a largely unrestrained version of private property maximized the welfare of the poorest as well as those better off. Thus Bentham in his Principles of the Civil Code explicitly considers the question of whether the poor benefit from the laws of property:

[L]aws, in creating property, have been benefactors to those who remain in their original poverty. They participate more or less in the pleasures, advantages, and resources of civilized society: their industry and labour place them among the candidates for fortune: they enjoy the pleasures of acquisition: hope mingles with their labours ... [A]ll things considered, the protection of the laws contributes as much to the happiness of the cottage, as to the security of the palace. $^{23}$

From this vantage point private property not only satisfied the utilitarian criterion of the greatest good of the greatest number, but also the yet to be named Rawlsian difference principle. As far as Bentham was concerned, this was the system that did the best by its least well-off members.

21 J. Bentham, Principles of the Civil Code (1838), Works of Jeremy Bentham, ed. John Browning, vol. 1 (reprinted, New York 1962).

22 Bentham, Civil Code, p. 309.

23 Bentham, Civil Code, p. 309. 
This was the utilitarian creed as it came down to John Stuart Mill. ${ }^{24}$ The institution of private property served the greatest good in at least two ways. Indirectly it gave rise to our sense of justice, while directly it contributed massively to the material welfare of prosperous and poor alike. It was this creed that Mill took great exception to. In particular, John Stuart Mill raised serious doubts about the justice of the institution of private property as it appeared in the real world. At root Mill rejected the all-or-nothing choice offered by the earlier utilitarians. He saw the economic world as far more malleable than the one they described. As a result, Mill was highly ambivalent about the institution of private property.

Mill could be a harsh critic. He asserted that in its then-present state, the institution of private property led to a situation in which the produce of labor was apportioned

almost in an inverse ratio to the labour - the largest portions to those who have never worked at all, the next largest to those whose work is almost nominal, and so in a descending scale, the remuneration dwindling as the work grows harder and more disagreeable, until the most fatiguing and exhausting bodily labour cannot count with certainty on being able to earn even the necessaries of life. ${ }^{25}$

If private property actually necessitated such a state of affairs he made clear that he would prefer communism with all its 'difficulties'.

In effect Mill turned the earlier utilitarian position on its head. Rather than giving rise to and reaffirming our sense of justice, the real-world institution of private property continually runs afoul of that sense. For Mill justice is defined as 'the appropriate name for certain social utilities which are vastly more important, and therefore more absolute and imperative, than any others are as a class'. ${ }^{26}$ The excesses of private property are unjust.

More specifically, as to its material productivity, Mill argued that as then constituted private property did poorly by the least advantaged and failed to maximize the greatest good of the greatest number. Like earlier utilitarians Mill sees the welfare of the worst off member and the representative member of society moving largely in tandem. But

24 The sharp contrast drawn here between Bentham and Mill may be somewhat oversimplified. For a nuanced reading of Bentham's theory of property see P. J. Kelly, Utilitarianism and Distributive Justice (Oxford, 1990). Kelly argues that Bentham's defense of private property was anchored in his endorsement of personal freedom. This reading moves Bentham closer to John Stuart Mill and Rawls's 'liberalism of freedom' discussed in the last section.

25 John Stuart Mill, Principles of Political Economy (1848), reprinted in Collected Works of John Stuart Mill, ed. J. M. Robson, vol. 2 (Toronto, 1965), p. 207.

${ }_{26}$ John Stuart Mill, Utilitarianism (1861), reprinted in Collected Works of John Stuart Mill, ed. J. M. Robson, V. 10 (Toronto, 1969) Mill notes that he sees no conflict of this definition with Kant's approach to morality. 
unrestricted private property has done less than well by both. Justice for Mill requires that society's institutions do well by both of these. For Mill the institution of private property as he found it allowed far too much field for the baser, largely unproductive, aspects of self-interest. To achieve justice and the greatest flowering of material progress, Hume's exercise in rechanneling the forces of self-interest needed some considerable assistance from organized society.

But according to Mill, the institution could be salvaged. His argument was not a rejection, but an ambivalent, or at least highly conditional, endorsement. Thus Mill held out for a greatly reformed and cleansed private property. ${ }^{27}$ Mill makes a case for a 'principle of private property [which] has never yet had a fair trial in any country':

The laws of property have never yet conformed to the principles on which the justification of private property rests. They have made property of things which never ought to be property, and absolute property where only a qualified property ought to exist. They have not held the balance fairly between human beings, but have heaped impediments upon some, to give advantage to others; they have purposely fostered inequalities, and prevented all from starting fair in the race. That all should indeed start on perfectly equal terms is inconsistent with any law of private property: but if as much pains as has been taken to aggravate the inequality of chances arising from the natural working of the principle, had been taken to temper that inequality by every means not subversive of the principle itself; if the tendency of legislation had been to favour the diffusion, instead of the concentration of wealth - to encourage the subdivision of the large masses, instead of striving to keep them together; the principle of individual property would have been found to have no necessary connexion with the physical and social evils which almost all Socialist writers assume to be inseparable from it. ${ }^{28}$

Mill in turning on Hume's perfect property rights anticipates Rawls's argument from justice. Both Mill and Rawls accept the insight of Hume's social psychology, but both maintain the incompleteness of the transformation in the historical forms of the institution. Justice requires more than private property plain and simple.

But Mill in opening the debate over justice and property had posed a question he was hardly capable of answering. The utilitarian position required him to search for the best possible institutional structure, but Mill hardly had the tools to identify a clear optimum. Having broken Hume's tight generative (and highly speculative) link between justice and historic realizations of private property, Mill is left with a truly mind-boggling, perhaps even impossible, problem of designing an optimal system. It is precisely this problem that Rawls has inherited.

27 Mill, Principles, p. 208.

28 Mill, Principles, p. 209. 
And Rawls, like Mill before him, produces only a thin defense of his idealized system of a property-owning democracy.

\section{AMBIVALENCE: RAWLS AND MILL ON MATERIAL WELLBEING}

Like Mill, then, Rawls embraces an ideal form of property with only passing suggestions (following Meade) of what types of legislation might help move an economy in that direction. What we really learn from Rawls's discussion is that the institution of private property is highly problematic in precisely the Millean sense. When left to laissezfaire mechanisms it leads to powerful concentrations of wealth that violate Rawls's principles of justice and Mill's most important social utilities.

Rawls maintains that justice is consistent with a tamed form of private property, but that justice is at odds with the aggressive acquisitiveness often associated with that institution. Where the early utilitarian defense for private property is fundamentally linked to the abundance (Bentham's word) that private property was supposed to generate, Rawls is actually suspicious of great material wealth. And he certainly doesn't see material progress of an economy as central to justice: 'It is a mistake to believe that a just and good society must wait upon a high material standard of life.' And, he goes on to state, 'great wealth. . . beyond some point is more likely to be a positive hindrance, a meaningless distraction at best if not a temptation to indulgence and emptiness'. ${ }^{29}$

Rawls is explicit that the difference principle 'does not require continual economic growth over generations to maximize upward indefinitely the expectations of the least advantaged measured in terms of income and wealth'. And here he explicitly invokes Mill. Rawls suggests, 'We certainly do not want to rule out [John Stuart] Mill's idea of a society in a just stationary state where (real) capital accumulation may cease. ${ }^{\prime 30}$ This seems almost an endorsement of that state.

Quite simply, Rawls is ambivalent about private property and its historic role in encouraging the accumulation of capital. By contrast, Rawls is not ambivalent about his conception of competitive markets, which he suggests are central to both liberal socialism and propertyowning democracies. ${ }^{31}$ Markets achieve efficiency, a virtue that Rawls doesn't question. They also allow for a type of procedural equality that Rawls finds quite attractive.

\footnotetext{
29 Rawls, Justice, p. 290.

30 Rawls, Restatement, p. 159.

31 Rawls is unconcerned or perhaps unaware of Austrian arguments that product markets cannot be easily separated from investment markets.
} 
Where Rawls strongly endorses markets, he never gives an argument actually in favor of private property in the means of production. His discussion of property is almost always in terms of the constraints to be placed on it, not in terms of its positive role. The only exception to this observation is where Rawls considers 'the right to hold and to have the exclusive use of personal property'. Unlike ownership of the means of production, a right to personal property ${ }^{32}$ is 'basic' to the extent that it allows 'a sufficient material basis for personal independence and a sense of self-respect, both of which are essential for the adequate development and exercise of the moral powers'. ${ }^{33}$ Personal property is very central to Rawls's conception of self-respect. It forms an extension of one's personality. But ownership of the means of production plays no such role.

Rawls explicitly states that the institution of private property, even in the tame form of the property-owning democracy, is not necessary to maintain a reasonable level of material progress. Liberal socialism, he suspects, can also meet these requirements. Liberal socialism, Rawls argues (and perhaps Mill would agree), is also consistent with the demands of justice. Thus those principles don't fully determine the basic structure but rather 'set out in a schematic way the outlines of a just economic system that admits of several variations'. He goes on to suggest that the choice between these two regimes must depend on 'the traditions, institutions, and social forces of each country, and its particular historical circumstances' ${ }^{34}$ A determination between property-owning democracy and liberal socialism is left to legislative debate.

Exactly what those historical and social conditions might be is never squarely addressed. Rawls has a low opinion of economic knowledge and certainly doesn't suggest that we know much about the relation between private property and the performance of the economy. 'Often the best we can say of a law or policy is that it is at least not clearly unjust. The application of the difference principle in a precise way normally requires more information than we can expect to have. . .35 While it is relatively easy to assess when the first principle of equal liberty is violated, it is 'comparatively rare' that we can determine whether the 'social and economic policies regulated by the difference principle' are just. Faced with such uncertainties, Rawls's retreat to

${ }^{32}$ Rawls includes 'dwellings' and 'private grounds' in the category of 'personal property' and apparently doesn't consider such capital as part of the 'means of production'.

33 Rawls, Restatement, p. 114.

${ }_{34}$ Rawls, Justice, p. 274.

35 This seems almost like an admission of the impossibility of determining the justness of some subset of regimes. 
rather vague statements about historical conditions may reflect little more than a willingness to be governed by traditional opinion.

Given his Millean ambivalences about private property, Rawls goes this far toward justifying the institution, but no further. He accepts a property-owning democracy much constrained by efforts to promote a more equal distribution of wealth. This is a thin and highly conditional acceptance, not a strong defense of private property.

\section{RAWLS, MILL, AND THE LIBERALISM OF FREEDOM}

In A Theory of Justice and succeeding works, Rawls references a number of contemporary economists including Arrow, Baumol, Sen, Koopmans, Buchanan, and most fundamentally Meade. But much more than a conversation between Rawls and modern economists, A Theory of Justice shows us a conversation between Rawls and John Stuart Mill. Ultimately, Rawls wants to view Mill as an 'exemplar... of the liberalism of freedom' along with Kant and Hegel. Rawls sees his own work as anchored in that tradition. ${ }^{36}$ By including Mill in his camp, Rawls claims to have won Mill over from the classical utilitarians, Bentham, James Mill and Sidgewick, a camp he labels the liberalism of happiness. While these early utilitarians 'confirm the liberal freedoms', they take as their first principle the greatest happiness summed over all individuals. ${ }^{37}$

Rawls' A Theory of Justice (at least as originally written) can be viewed as an elaborate attempt to solidify the claims of the liberalism of freedom vis à vis the liberalism of happiness. ${ }^{38}$ In a sense John Stuart Mill is the crucial borderline figure in this contest. One can imagine Rawls as essentially attempting to convince (browbeat?) Mill into renouncing the classical position and more fully accepting his (i.e. Mill's) inner or deeper tendencies.

Rawls's understanding of the liberalism of freedom and its relation to private property is most clearly presented in his discussion of Hegel. In Lectures on the History of Moral Philosophy, Rawls considers at some length Hegel's approach to private property. For Hegel the material, utilitarian consequences of the institution of private property are beside the point. For Hegel the value of the institution is that it allows the free expression of individual will.

${ }^{36}$ J. Rawls, Lectures on the History of Moral Philosophy, ed. B. Herman (Cambridge, Mass., 2000), p. 330.

${ }_{37}$ Rawls, Lectures, p. 366.

${ }^{38}$ In later works, such as Justice as Fairness: A Restatement, the central concept is a somewhat scaled down 'political liberalism', which is meant as a base rather than a complete philosophy. However, it shares the general outlook of the liberalism of freedom. 
It is hard to imagine John Stuart Mill going this far. But still there seems considerable truth to Rawls's claims concerning Mill. Mill, like Rawls, qualifies the centrality of material progress and its contribution to utility in favor of utopian systems focused on justice and freedom. Given such priorities the question of private property remains as a potentially charged embarrassment. Both philosophers avoid embarrassment by accepting the institution with only a highly conditional defense.

Rawls, like Mill, was ambivalent about progressive claims for the institution of private property. Mill was convinced that private property in the context of nineteenth-century Britain had generated a system in which contribution and reward were only loosely correlated. Mill fell back on a sterilized form of property ownership, one which had been cleansed of the most offending qualities. He thinks such a reformed system can stand up to liberal versions of collective ownership, although he is reluctant to choose between them. Rawls follows Mill in setting up a comparison of idealized system to idealized system and then avoiding a choice between these regimes. Rawls calls this approach 'realistically utopian'. ${ }^{39}$

We are left with neither a defense of private property nor a full determination of the justice of alternative regimes. In following his Millean strategy Rawls avoids the hardest questions raised by modern economic history. A clearer position would seem to be required. Rawls's explicit theory of justice and Mill's implicit one demand more. Even in their idealized, utopian forms, it is highly doubtful that each of these regimes, a property-owning democracy and a liberal democratic socialism, should do just about as well by the least advantaged members of their respective societies. In the end, Rawls's thin Millean defense of private property very much begs the question of justice he did so much to define.

jpersky@uic.edu

${ }^{39}$ Rawls, Restatement, p. 13. 